811.163.41'342.8

811.163.41'37

https://doi.org/10.18485/sj.2020.25.1.6

МИЛОРАД П. ДЕШИЋ

Универзитет у Београду

Филолошки факултет
Оригинални научни рад

Примљен: 15. 10. 2019.

Прихваћен: 15. 01. 2020.

\title{
СЕМАНТИЧКО ОБИЉЕЖЈЕ ЖИВО/НЕЖИВО И СРПСКИ СТАНДАРДНИ АКЦЕНАТ
}

У овом раду дефинише се семантичко обиљежје живо/неживо и утврђује које ентитете обухвата. Констатује се да је оно посебно присутно, поред именица, код придјева, замјеница, бројева, глагола и узвика. Грађа показује да су категорија падежа и категорија рода међузависне, као и да је живо/неживо у тијесној вези са српским књижевним акцентом.

Кључне ријечи: живо/неживо, акценат, једнина, мушки род, акузатив, локатив, вокатив, полисемија.

1. Семантичко обиљежје живо/неживо је веома важна карактеристика српског књижевног језика, као, усталом, и словенских језика уопште. Она је уско повезана са питањима лексичког и граматичког значења, уз које иду конкретно/материјално и апстрактно/нематеријално значење, и питањима природног и граматичког рода. Наиме, лексичко значење се схвата као семантичка информација лексичких јединица, а граматичко значење као семантичка информација граматичких елемената. Род се разумије као граматичка категорија (мушки, женски, средњи) која се дијели на природни род (везан за пол) и граматички род (који се не односи на пол). У овом раду биће ријечи о односу обиљежја живо/неживо према српском књижевном акценту.

"milorad.desic@gmail.com 
2. Још давно је Ђуро Даничић у Српским акиентима, полазећи од Вуковог Српског рјечника, запазио да поједине групе именица мушког рода, које се односе на живо и неживо, могу имати исти акценат у скоро свим облицима, осим у локативу једнине. На тај начин групе се разбијају на посебне акценатске типове или подтипове, зависно од класификационог критеријума. Тако, на примјер, у једносложним именицама са дугосилазним акцентом готово у свим падежима акценат се не мијења у погледу категорије живост/неживост: враิح : враิга, знаิк : знаิка - друิг : дрйгови, керр : кёрови; зйд : зӥдови, ре̂n : рёпови;

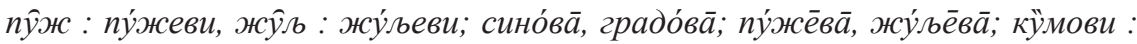
кумо̀вима, грӓдови : градовима. Наравно, у данашње вријеме неке алтернације

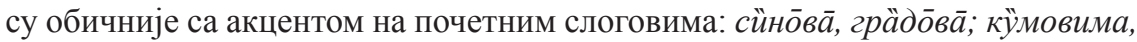
грӓдовима (већ је Даничић слушао и облике: грӓдовима, глӓсовима). Супротно од претходних примјера стоје двије подгрупе именица у локативу једнине, подијељене с обзиром на категорију живо/неживо. У првој подгрупи налазе се именице које у овом падежу дугосилазни акценат замјењују дугоузлазним:

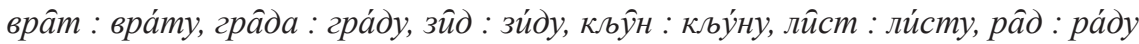
итд. Очигледно је да се ове ријечи односе на неживо. За другу подгрупу Даничић каже: „Само у речи овог реда које значе чељад и животињу налазим да се акц. не мења у реченом падежу, н.п. вуิк у сказ. остаје вуิку". Аутор наводи листу од 39 именица, међу којима и сљедеће: друг, зеи, јеж, кер, кнез, кос, муж, пуж, син, ирв. Неколико напомена уз листу: 1) на њој се грешком нашла именица зве̂р (ијек. звйјер), која је у Вуковом Рјечнику женског рода (у стиху И кренуше звијера арслана облик звијера употријебљен је због епског десетерца); 2) збирна именица пүิк 'људи, маса, свјетина' више припада првој подгрупи; 3) Решетар, приређивач Српских акцената, исправио је акценат двију именица: умјесто Вуковог груิj ('врста морске рибе'- Дубровник) и жбйр ('ухода' - Приморје) требало је да стоји грӥј и жбӥр; 4) Даничићев чврљ не постоји у Вуковом Рјечнику - вјероватно штампарска грешка: требало је да стоји чкв $\hat{\boldsymbol{p}}_{\boldsymbol{b}}$ ('(у Ц. г.) некака црна тица, колико кос') (19-22).

Једносложне именице, које се односе на живо и неживо, чувају крат-

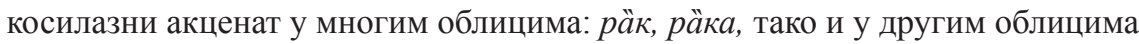

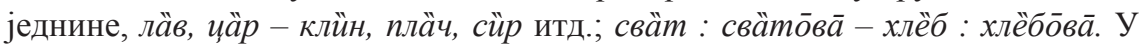
ген. мн. може да се јави и дугосилазни акценат: $Г \ddot{p} к: Г \bar{p} \kappa \bar{a}, P \ddot{y} c: P \hat{y} c \bar{a}, m u ̈ \hbar$ :

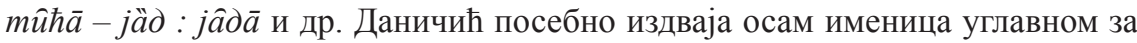
неживо које у лок. једнине имају краткоузлазни акценат: „У сказ. једн. мења се у неколико између оваких речи " на ': Влӓх, Вла̀ху; прӓг : пра̀гу; пр̈ст : пр̀сту; рӓт : ра̀ту; скӱп : ску̀пу; сплёт : сплѐту; чӓс : ча̀су; чӧт ['бријег, брежуљак']: чо̀ту”. У вези са паром Влӓx, Вла̀xy, Решетар напомиње: „Али је то сигурно само кад значи нешто неживо (неки крај „Стари Влах” у Србији) а не кад значи нешто живо (Румуна); у В. та промјена није уопће забиљежена”. (24-25) 
Велика је група двосложних именица с обиљежјем живо/неживо и са краткосилазним акцентом и постакценатском дужином које не мијењају акценатску слику у цијелој парадигми или то чине само у неким падежима: тип

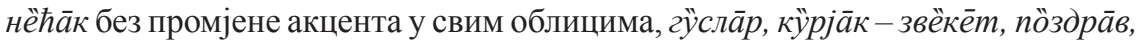

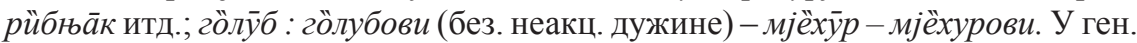

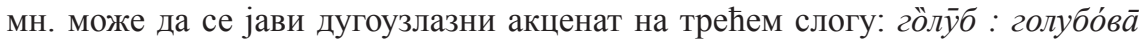
- лӥша̄j : лишаје́в $\bar{a}$, али данас је обичнији акценат на почетним слоговима:

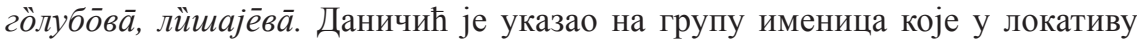

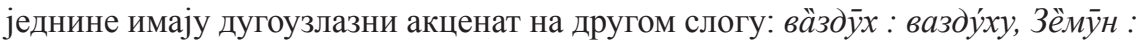
Зему́ну, ӧблӣк : обли́ку, пӧгле̄д : погле́ду, сӓла̄ш : сала́шу, слйча̄j : случа́jy итд. У данашње вријеме ове именице имају често и акценат на почетним слоговима: вӓздуxy, Зёмууну и др. Даничићево запажање о њиховом семантичком обиљежју исказано је на сљедећи начин: „Знатно је што међу речима у којих ова промена бива, нема ни једне која значи што живо”. (36-38)

У Српским акиентима налазе се напомене и о тросложним именицама са краткосилазним акцентом и неакц. дужином на трећем слогу. У већини примјера, који се односе на живо и на неживо, акценат се не мијења у цијелој

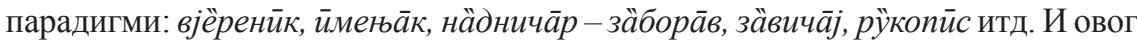
пута дошле су до изражаја специфичности локатива једнине. Наиме, у мањој групи именица јављају се у овом падежу узлазни акценти на трећем слогу, дуги или кратки: дӧгађ $\bar{j} j$ : догађа́jy, ӧбича̄j : обича́jy, nöрођа̄j : порођа́jy; дӧгово̄p : договоेру, нӓгово̄p : наговоेру, рӓзгово̄p : разговоेру. У савременом српском

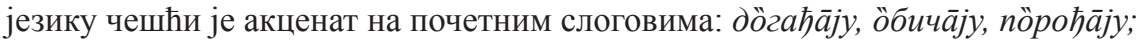
дӧгово̄py, нӑговоррy, рӓзгово̄py. Даничић није коментарисао локатив једнине ових именица у вези са живошћу/неживошћу, али јасно се види да овај облик упућује на нешто неживо (46).

3. Категорија живо/нежсив обухвата различите ентитете. Поткатегорија живо односи се на жива бића (људе и животиње, али не и на биљке), као и на оно што се сматра таквим: натприродна и митска бића - анђео, бог, демон, дракон, Ђаво, змај, кентаур. Ту спадају и бића која нису више жива: мртваи и покојник. Поткатегорија неживо односи се на предмете (широко схваћене као конкретне / материјалне и апстрактне / нематеријалне), на биљке, појаве, својства итд. Семантичко обиљежје живо / неживо присутно је, поред именица, код придјева, замјеница, бројева, глагола, па и узвика. С обзиром на ово обиљежје, према именици као главној ријечи или као субјекту реченице граматички се управљају придјеви, придјевске замјенице, број један и редни бројеви, глаголи. Наравно, важну улогу има и лексичко значење.

4. Кад се расправља о категорији живо/неживо, у лингвистичкој литератури се посебно описује стање у словенским језицима. Помињу се различити облици именица мушког рода у једнини и у множини, помоћу којих се разликује живо од неживог. Често се истиче, поред осталог, подударање облика акузатива 
једнине именица мушког рода са обликом генитива да би се изразило живо или са обликом номинатива да би се указало на неживо (једнакост облика значи и једнакост акцената). Управо је ово случај са српским књижевним језиком: Видим пријатеља $($ акуз. = ген.) - Видим прозор (акуз. = ном.). У даљем излагању видјећемо како се обиљежје живо/неживо одражава на српски књижевни акценат, не само код именица него и код других врста ријечи.

5. Категорија живо/неживо, у оквиру полисемије, потпуно се остварује код неких именица мушког рода. У ствари, поткатегорија живо везује се за облик вокатива. Зашто баш за њега? Зато што вокатив служи за директно обраћање некоме или скретање пажње на нешто, за дозивање - означавајући тиме нешто реално живо, док би обраћање нечему неживом могло да се догоди само у посебним и ријетким приликама - чиме би вокатив упућивао на нешто само потениијално живо. Уобичајено одсуство облика вокатива у значењима за неживо, са често измијењеним акцентом, доводи до смањења броја чланова акценатске парадигме и/или корпуса акцентованих облика. У сљедећим примјерима видјећемо, полазећи од основног значења, како се смјењују семантичке поткатегорије, како се иде од живог ка неживом и од неживог ка живом:

исnѝра̄ч, -а́ча м направа за испирање нечега (неживо) - (В йспира̄чу) онај који нешто испира (живо);

испра̀вљ, $\overline{\boldsymbol{a}} \boldsymbol{\text { , }}$-а́ча м (В йсправља̄чу) онај који исправља (живо) - уређеј за претварање наизмјеничне струје у једносмјерну (неживо);

кònāu $\boldsymbol{u}$, -а́ча м (В кӧпа̄чу) онај који копа (живо) - оруђе којим се копа (неживо);

$\boldsymbol{н} \dot{c} \boldsymbol{c} \bar{u} \boldsymbol{u}$, -а́ча м (В нӧса̄чу) онај коме је занимање преношене терета (живо) - стуб, греда, подлога која носи конструкиију грађевине (неживо);

$\boldsymbol{n}(\mathbf{j}) \grave{\iota} ш \bar{a} \kappa$, -а́ка м (В п(j)ёша̄че) онај који иде пјешке (живо) - једна од шаховских фигура (неживо);

цвеิт/цвйјет м орган за размножавање код виших биљака (неживо) - (В цвеิте/ цвйјете) мила, драга или врло лијепа особа - Цвијете мој, дођи! (живо).

Питање је да ли се у овим примјерима акузатив једнине слаже са генитивом кад је ријеч о живом или са номинативом кад је ријеч о неживом. У наведеним именицама углавном се поштује основно правило, али, ипак, пјешак као шаховска фигура (неживо) не држи се правила, па се акузатив подудара са генитивом: Помјерио је пјешака. Ово је тема за ширу расправу и за неку другу прилику. Овдје ћемо само додати супротан примјер забиљежен у РСАНУ - именица означава живо, али се акузатив слаже са номинативом:

јѐзик м покретљиви мишићни орган у усној дупљи код човјека и виших животиња (неживо) - заробљеник који треба да да̂ податак о непријатељској војсци (живо). - Имао је задатак да ухвати „жив језик”.

6. Одсуство облика вокатива у значењима за неживо није усамљен случај. Наиме, у деклинацији и конјугацији честа је појава да поједине категорије нису комплетне, нешто им недостаје: једнина или множина код именица; од- 
ређени или неодређени вид, компаратив код придјева; императив код глагола итд. Ова појава директно утиче на структуру српског акценатског система - долази до смањења броја чланова акценатских парадигми (броја акценатских алтернација) и/или корпуса акцентованих облика. Због значаја ових чињеница, детаљније ћемо размотрити типичне случајеве.

7. Неке именице мушког рода имају облик једнине и множине, али понекад се једнински облик односи на множински (синегдоха):

У Првом свјетском рату српски сељак је највише страдао. (сељак = сељаци)

Ове године кромпир је добро родио. (кромпир = кромпири)

Изостајањем облика множине изостају и њихови акценти, који су једнаки са једнинским акцентима (сеља́ųu, сеља́u̧има, сеља́ке - тако и код именице кро̀мnйp), али у ген. мн. дугоузлазном акценту додаје се постакценатска дужина

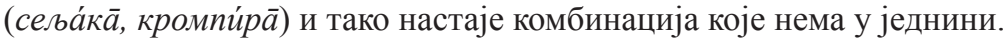

8. Један број именица мушког рода (градивне, збирне и друге) имају само акцентоване облике једнине:

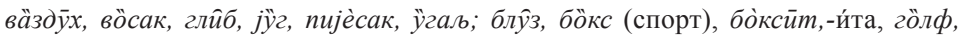

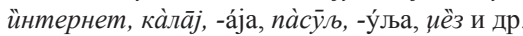

Ова група именица са различитим акцентима, домаћег и страног поријекла, припада поткатегорији неживо.

9. Поткатегорији неживо припадају и именице мушког рода које имају само акцентоване облике множине (pluralia tantum): ана́ли, нога́ри. Међутим, код неких именица долази до преплитања једнинских и множинских акцентованих облика, па се јављају примјери као:

äдитӣв, àymo-dёо,-де́ла/àymo-дйо,-дијѐла (обично у множини); бѐнзйн,-и́на (ријетко у множини).

Неки пут се множински облици као једини у употреби везују само за одређено значење полисемичне именице:

мемо̀а̄p, - а́ра м 1. мн. спис, дјело у којем аутор износи своје успомене о догађајима које је доживио и о људима које је познавао. 2. званичан акт, спис у дипломатској преписии.

10. Властито име је посебно име неког лица, животиње, географског појма и др. Узмимо за примјер лично име, које упућује на особу са одређеним својствима и тиме показује да име има одређено значење. Током времена особа се мијења, једне особине добија а друге губи, али име се не мијења. Оно остаје захваљујући основним, стабилним својствима. На основу њих препознајемо поједине особе, па кажемо: Прилази ми један пријатељ - није Мирослав него Владимир. Пошто овакве именице означавају појмове који се узимају као индивидуални, природно је да немају граматичку категорију множине. Ипак, ако је ријеч о већем броју различитих појмова са истим именом, јављају се 
множински облици: Догодило се да се у истој групи туриста нађе неколико Милана. У овом случају именица Милан није употријебљена као властита у правом смислу, него више као заједничка, са значењем 'особа која носи име Милан' (Круз 2012: 394-396). Битно је истаћи још једну одлику личних имена: она се граматички понашају као семантичка поткатегорија живо и онда кад особа са одређеним именом није више жива - Драгана сам добро упамтио (акузатив = генитив).

11. У проучавање семантичке категорије живо/неживо важно је укључити и питања која се тичу антономазије, фигуре ријечи. Под њом се подразумијева употреба властите као заједничке или заједничке као властите именице (Багић 2015: 55). Анализираћемо мањи корпус заједничких именица (и понеке градивне), састављен од ријечи страног поријекла, а односи се на ствари, особе, животиње, мјерне јединице, производе итд. Властите именице обухватају различите појмове: цареве, војсковође, научнике, проналазаче, конструкторе, богове, државнике, књижевне ликове и уопште особе које се истичу по некој особини; затим мјеста, покрајине, компаније и уопште нешто познато. С обзиром на односе унутар категорије живо/неживо, цјелокупну грађу подијелили смо на три групе:

а) неживо:живо

àвzусm, осми мјесец у години - Aвгусm (=Величанствени) као титула Октавијана и каснијих римских царева (у латинском octavus $=$ ocmu $)$

а̀јншта̄јнијум, хемијски елемент - физичар А. Ајнштајн àмnерp, -е́ра, јединица за мјерење - физичар А. Ампер јачине електричне струје

бојкот, уздржавање од рада или - Ч. Бојкот, енглески управник посједа у Ирској, учествовања у нечему против којег су се Ирци борили ненасилним путем вâm (ген. мн. ва́тӣ), јединица - физичар Џ. Bam за мјерење снаге електричне струје ву̀лкан, -а́на, узвишење са отвором - Вулкан, бог ватре и ковачке вјештине код (кратером), кроз који из унутрашњости старих Римљана

Земље избијају (или су избијали) лава, гасови и пепео ж⿻йлетm, -е́та, специјални ножић - проналазач, Американац К. Џилет (према фр. за бријање изговору Жилет)

калашњѝков, врста аутоматске - конструктор, Рус Калашњиков пушке 
мака̀dа̄м, -а́ма, коловозни слој - шкотски инжењер -Макадам

израђен од уваљаног туцаника

и камене ситнежи, понекад и са

спојним материјалом

наполѐо̄ $\boldsymbol{\mu}$, -о́на, француски - француски цар и војсковођа Наполеон

златни новац

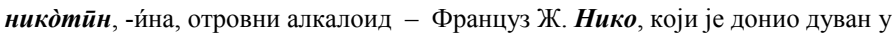

у листовима дувана

Француску

$\boldsymbol{~ в и ̆ т н , ~ ј е д и н и ц а ~ с и л е ~}$

- физичар, И. Њутн

$\boldsymbol{\partial} \boldsymbol{м}$, јединица за мјерење

- физичар, Г. С. $\boldsymbol{O}_{\boldsymbol{M}}$

електричног отпора

рѐндzен, апарат за снимање

- физичар, В. К. Рендген

помоћу рендгенских зрака

б) живо:живо

дӧберман, врста пса

- њемачки узгајивач Л. Доберман

донжу̀̄̄, -а́на, заводник,

- Дон Жуан, књижевни лик (фр. изговор)

љубавник

квйслинг, помагач, сарадник

- В. Квислинг, предсједник марионетске

окупатора

владе у Норвешкој у Другом свјетском рату

мёнтор, онај који некога

- Ментор, лик из Одисеје

поучава, савјетује и води у

неком послу

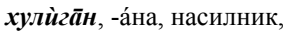

- презиме једне ирске породице у Лондону

силеџија

в) неживо : неживо

као̀лй $\boldsymbol{\mu}$, -и́на, глина од које

- Каолинг, мјесто у Кини

се прави порцелан

ка̀шмӣ̄p, -и́ра, фина тканина

- индијска покрајина Кашмир

од длаке кашмирске козе

фија́кер и фија̀кер, лакша

- париски хотел „Свети Фијакрије“

путничка запрежна кола,

кочија са покретним кровом

фüјаm, марка аутомобила

- Фијаm, италијанска фабрика аутомобила

uампа́ьац, њца, врста вина

- француска покрајина Шампања 
Под а) је цјеловита семантичка категорија (неживо : живо), док су под б) и в) у питању односи истоврсних поткатегорија (живо : живо и неживо : неживо). Видјели смо да на различите начине поткатегорије живо прелазе у поткатегорије неживо, односно да властите именице постају заједничке (понекад градивне). Претходној грађи додаћемо и примјер особеног народног именовања, гдје се, у разговорном језику, међу домаћим ријечима, на посебан начин остварује однос неживо:живо. Ријеч је о синтагми застава 101 (сто један), марки аутомобила која је, игром ријечи, преименована у синонимну именицу стојадин. До ове именице дошло се изостављањем заставе и преобликовањем стоิ јѐдан у слични стоја̀дин (неживо), који је настао угледањем на лично име Стоја̀дин (живо). Уосталом, елеменат живо задржао се у деклинацији (акузатив = генитив, иако је у питању нешто неживо : Купио сам стојадина).

Грађа показује да се властите именице и заједничке разликују по акценту. Као што је и очекивано, властите именице немају множинске акцентоване облике (смањен корпус), али их имају заједничке именице: àмпе̄p - ампе́ри, жѝлёm-жиле́ти, квйслинг - квйслинзи итд. Разлика може да постоји и у броју чланова акценатских парадигми, тј. броју акценатских алтернација. Тако, само код заједничких именица налазимо повећан број чланова акц. парадигме у ген. мн. : бојјкот - бӧјко̄та̄, рѐндген - рёндге̄н $\bar{a}$, а исту појаву могли бисмо срести код личних имена у вок. једнине: Наполѐо̄н - Нӓполео̆не (тог облика нема код заједничке именице наполѐо̆н).

Мали је број примјера за употребу заједничке именице као властите. У РСАНУ налазимо презиме Пѐшкйр (живо) постало од истоимене заједничке именице пѐшкйр (неживо):

Пѐшкӣp, презиме - пѐшкӣp, -и́ра, комад тканине намијењен за брисање руку и тијела, убрус

Разлика у акценту је у томе што се, у свакодневном говору, краткосилазни акценат са дужином јавља само у вок. једнине презимена (у природном мушком роду): Пёшкйру.

12. Деклинација и акценат презимена (поткатегорија живо) може да зависи од облика природног рода, мушког и женског. У РСАНУ ријетко се наводи генитив једнине презимена: Йћеваи, -ёвца. Најчешће се даје само облик номинатива: И́ъаи, Јӑzањаu. Зашто је то тако? Зато што се презимена на сугласник мијењају ако су мушка (Јо̀ван Јӓгањаи, Јо̀ван Јӓга̄њйа), али су непромјенљива ако су женска (Ма́pa Jàzaњau, Mápē Jăzaњъu). Значи, у женском презимену, у овом случају, има само један акцентовани облик, а међу онима који недостају нема ни облика са постакценатском дужином (Јӓга̄њц̧а), који срећемо у мушком презимену. Иначе, женска презимена на - $a$ су промјенљива: Миิлка Бӥрица, Мйлке̄ Бӱрицее. 
13. Природа категорије живо/неживо код придјева зависи од именице коју придјев одређује или субјекта реченице у којој се придјев јавља. Иако нам је основно лексичко значење познато без одређеног контекста, навешћемо ипак примјере за придјеве уздржљив (живо) и влажан (неживо):

уздрेжьив - који може да се уздржи, који се нерадо изјашњава. - Важио је за уздржсљивог човјека. Контролисао је своја осјећања, био је веома уздржжљив.

влӓжан - који садржи много влаге, засићен влагом. - Удисали смо влажан ваздух. У шуми је земља обично влажнна.

Потпуна акценатска слика ових придјева добија се кад се додају одређени вид (повећан број неакцентованих дужина) и компарација (промјена мјеста односно квалитета акцента и додате дужине):

уздружљив, одр. уздрџжљиви, комп. уздржљиивијй;

влӓжан, одр. влӓжнй, комп. вла̀жнијӣ.

14. За многе полисемичне придјеве карактеристично је неутрално понашање категорије живо/неживо, тј. присутне су обје поткатегорије (живо и неживо):

пйсмен - писмен човјек (умије да чита и пише): писмен текст (одликује се писменошћу, граматичком исправношћуи стилском дотјераношћу).

Слично је, такође без промјене акцента, и у примјерима:

зѐлен - зелена трава : зелен коњ; шкӧлскй - школска зграда : школски човјек; зла́тан - златан сат : златан младић и др.

15. Код неких придјева изостају одређене карактеристике: у основном облику (ном. једнине мушког рода) придјеви имају а) само неодређени вид, б) само одређени вид; в) немају компарације (у облицима присутна категорија живо/неживо). Одсуство претходних карактеристика значи одсуство великог броја акцентованих облика:

а) неодр.: брӓтов, Маิрков, ӧчев, сѐстрин;

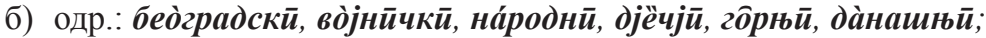

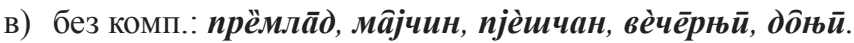

16. У РСЈ наведена су неколика придјева који се односе на жене у другом стању и који се употребљавају само у женском роду. Њихова семантичка обиљежја су: живо, људско, женско, а смањен им је корпус акцентованих облика:

брёменит/бремѐнит, -а, -о (у ж. роду:-а)(али: вријеме бременито опасностима); грӓвйдан, -дна, -дно (најчешће у ж. роду);

тру́дан, -дна, -дно (најчешће у ж. роду) (ријетко: Има трбух као да је трудан).

Можда би најбоље било да се овакви придјеви дају као одредница у женском роду: бременита, гравидна, трудна. Уосталом, тако је урађено у РСЈ са једним придјевом истог значења:

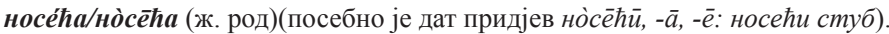


17. Најсиромашнији у акцентима су непромјењљиви придјеви страног поријекла и један домаћи, који немају ни акцентоване падежне облике ни одређени род:

брӓон, о̀кер, ро́зе, тёгет (боје, обично уз именице за неживо); та̀ма̄н, фёнси, фе̂р; на́лик (семантички неутрално).

Овдје је ријеч о минималном акценатском корпусу - постоји само акцентован основни облик.

18. Природа категорије живо/неживо код глагола зависи од субјекта реченице у којој се глагол јавља. Основно лексичко значење знамо без посебног контекста, али ми ћемо ипак дати примјере за глаголе причати (живо) и извирати (неживо):

при́чати - општити говором, разговарати. - Нисмо до сада причали о томе.

ѝзвирати - избијати, излазити на повриину земље (о води). - Ова велика ријека извире далеко одавде.

19. Употреба глаголских облика директно је условљена лексичким значењем. Категорија живо/неживо јавља се код полисемичних глагола, и то тако да се у поткатегорији неживо користи само треће лице једнине и множине неког облика и да се изоставља императив, јер његово основно значење (исказивање заповијести, захтјева, молбе) припада поткатегорији живо. Одсуство одређених акцентованих облика у неким значењима указује на смањење укупног акценатског корпуса глагола и на тијесну повезаност лексичко-семантичких и граматичких категорија:

вёнути/вѐнути, вёне̄м губити свјежину, сушити се (о биљци и њеним дијеловима). - Лишће вене. - фиг. губити снагу, слабити, мршавити (о човјеку). - У годинама си, али још ниси почео да слабиш, венеш.

наобла́чити се, нао̀бла̄чйм се прекрити се облацима, постати облачан. - Наоблачило се. - фиг. постати натмурен, намритити се. - Ако ти то кажем, одмах ћеш се наоблачити.

лйстати, -а̄м добијати, развијати листове (о биљкама). - Шума листа. - окретати листове (књиге, новина и сл.), прелиставати. - Често листам ту књигу.

ѝћu, ӥде̄м/ѝде̄м кретати се корачајући, ходати. -Треба да идеш много брже. - имати прођу, продавати се. - Његове књиге добро иду.

20. Код неких глагола поткатегорија живо дијели се на људско : животињско и животињско : људско:

по̀јести, по̀једе̄м сажвакати и прогутати сву храну. - Појели смо цијело пиле. - оштетити бушећи, гризући (о инсектима). - Мољци су појели јакну.

лӓјати, лӓје̄м оглашавати се гласовима карактеристичним обично за пса. - Пас је лајао на мачку. - пеј. говорити о некоме ружно, увредљиво. - Зашто стално лајеш против њега?

Глаголи са значењем животињско понашају се у овим примјерима као глаголи за неживо у претходној тачки: употреба само трећег лица једнине и множине и изостављање императива. 
21. Узвици семантички покривају више тематских области: 1) дозивање, скретање пажње - $\hat{j}$ (живо - људско); 2) изражавање личних осјећања, расположења (одушевљење, дивљење, радост, чуђење, бол, жалост, љутња и др.) - äx, ëx, üx, jäo, ÿx и др. (живо - људско); 3) подражавање гласова животиња - äв (живо - животињско); 4) дозивање или тјерање животиња - гйи (обично поновљено), мӓи (и ма́ц, ма̀ц или сл., обично поновљено), ӥм, шӥu (живо - животињско); 5) подражавање природних звукова - бӱм (обично поновљено), дӱм, mpäc/mpâc (неживо).

У рјечницима, нпр. у РСЈ, често се уз дефиницију узвика наводи и примјер:

jäo - узв. 1. за изражавање бола, жалости, туге... - Јао, куку мени...3. за изражавање радости, дивљењ $а$. - Јао, што се радујем!

Узвик јао, узет сам за себе, изражава емоционално стање говорника. С обзиром на специфичности акцента ове врсте ријечи, јао може бити прозодијски градуабилно, што значи да се с појачаним интензитетом осјећања појачава и акценат узвика, као и његова висина и дужина. Насупрот оваквом значењу, експресивном, стоји дескриптивно значење, изражено реченицама које се у примјерима налазе иза узвика. У ствари, експресивно значење је једнако дескриптивном (јао = куку мени, јао = што се радујем), само је разлика у начину означавања (Круз 2012: 200/201).

22. У лингвистичкој литератури скретана је пажња на међузависност категорије падежа и категорије рода (Лајонс 1970: 226). У српском језику облик акузатива једнине именица мушког рода подудара се са обликом генитива да би се изразило живо или са обликом номинатива да би се указало на неживо (једнакост облика значи и једнакост акцената). Постоје и групе именица мушког рода које у локативу једнине посебним акцентом истичу категорију живо/неживо.

Уобичајено је одсуство вокатива, у оквиру полисемије, у значењима за неживо. Ово није усамљен случај. Наиме, у деклинацији и конјугацији честа је појава да поједине категорије нису комплетне, нешто им недостаје: једнина или множина код именица; одређени или неодређени вид, компаратив код придјева; императив код глагола итд. То доводи до смањења броја чланова акценатске парадигме и/или корпуса акцентованих облика.

Деклинација и акценат презимена (поткатегорија живо) може да зависи од облика природног рода, мушког и женског: презимена на сугласник мијењају се ако су мушка, али су непромијењљива ако су женска.

Семантичко обиљежје живо/неживо уочљиво је, поред именица, код придјева, замјеница, бројева, глагола и узвика. С обзиром на ово обиљежје, према именици као главној ријечи или као субјекту реченице граматички се управљају придјеви, придјевске замјенице, број један, редни бројеви и глаголи. 
Категорија живо/неживо јавља се код полисемичних глагола, и то тако да се у поткатегорији неживо користи само треће лице једнине и множине неког облика и да се изоставља императив.

За узвике је карактеристична прозодијска градуабилност и експресивно значење, као и дескриптивно значење.

\section{ЛИТЕРАТУРА}

Багић 2015: K. Bagić, Rječnik stilskih figura (drugo izdanje), Zagreb: Školska knjiga.

Галмиш 1975: M. Galmiche, La sémantique générative, Paris: Librairie Larousse.

Даничић 1925: Ђ. Даничић, Српски акиенти, Београд - Земун: Српска краљевска академија.

Караџић 1986/1987: В. С. Караџић, Српски рјечник (1852), Београд: Просвета.

Кристал 1988: D. Kristal, Enciklopedijski rečnik moderne lingvistike, Beograd: Nolit.

Kруз 2012: A. Cruse, Meaning in Language, An Introduction to Semantics and Pragmatics, Oxford: Oxford University Press.

Лајонс 1970: J. Lyons, Linguistique général - introduction à la linguistique théoriqie, Paris: Librairie Larousse.

Лич 1987: G. Leech, Semantics, Harmondsworth, Middlesex: Penguin Books Ltd.

Пикош 1980: J. Picoche, Précis de lexicologie française, Amiens: Nathan - Université, Information, Formation.

РСАНУ 1959-: Речник српскохрватског књижевног и народног језика, Београд: САНУ, Институт за српски језик.

PCJ 2018: Речник српскога језика (друго издање), Нови Сад: Матица српска.

Русский яаык 1979: Русский Яаык - Энциклопедия, Москва: Советская энциклопедя.

Станојчић 2010: Ж. Станојчић, Граматика српског књижевног језика, Београд: Креативни центар.

Чермак 2010: F. Čermák, Lexikon a sémantika, Praha: Nakladatelství Lidové noviny. 


\section{SEMANTIC MARKER FOR ANIMATE/INANIMATE AND STANDARD SERBIAN STRESS}

\section{Summary}

In Serbian, the accusative form of singular masculine nouns is identical to genitive form when denoting animate and to nominative form when indicating inanimate, respectively (identical forms also imply identical stress). There are also groups of masculine nouns which in singular locative form distinguish between animate and inanimate by use of a special stress.

With respect to polysemy, the absence of vocative is common for inanimate category. However, this is not an isolated case. Namely, both declension and conjugation often include certain categories that are incomplete, with some elements missing: singular or plural form in nouns; definite or indefinite form, or comparative degree, in adjectives; imperative mood in verbs, etc. This results in a reduced number of constituents of stress paradigm and/or of stressed forms.

The animate/inanimate category occurs in polysemic verbs, where for the inanimate category only the third person of singular and plural form is used and the imperative mood is omitted.

Keywords: animate/inanimate, stress, singular, masculine, accusative, locative, vocative, polysemy. 